\title{
Analysis Of Hindu Widowhood In Indian Literature
}

\author{
Dipti Mayee Sahoo \\ Asst. Prof. SociologyTrident Academy of Creative technology,Bhubaneswar
}

\begin{abstract}
In ancient India, women occupied a very important position, in fact a superior position to, men. It is a culture whose only words for strength and power are feminine -"Shakti" means "power" and "strength." All male power comes from the feminine. Literary evidence suggests that kings and towns were destroyed because a single woman was wronged by the state. For example, Valmiki's Ramayana teaches us that Ravana and his entire clan was wiped out because he abducted Sita. Veda Vyasa'sMahabharatha teaches us that all the Kauravas were killed because they humiliated Draupadi in public. ElangoAdigal'sSillapathigaram teaches us Madurai, the capital of the Pandyas was burnt because PandyanNedunchezhiyan mistakenly killed her husband on theft charges. "In Hinduism, the momentous event of a foundation at one point in time, the initial splash in the water, from which concentric circles expand to cover an ever-wider part of the total surface, is absent. The waves that carried Hinduism to a great many shores are not connected to a central historical fact or to a common historic movement. "
\end{abstract}

Key words:- Feminine, sakti, strength, humiliation, power.

\section{INTRODUCTION}

In this age of ascending feminism and focus on equality and human rights, it is difficult to assimilate the Hindu practice of sati, the burning to death of a widow on her husband's funeral pyre, into our modern world. Indeed, the practice is outlawed and illegal in today's India, yet it occurs up to the present day and is still regarded by some Hindus as the ultimate form of womanly devotion and sacrifice. The term Sati is derived from the original name of the goddess Sati, also known as Dakshayani, who self-immolated because she was unable to bear her father Daksha's humiliation of her (living) husband Shiva. Sati as practice is first mentioned in 510 CCE, when a stele commemorating such an incident was erected at Eran, an ancient city in the modern state of Madhya Pradesh. The custom began to grow in popularity as evidenced by the number of stones placed to commemorate satis, particularly in southern India and amongst the higher castes of Indian society, despite the fact that the Brahmins originally condemned the practice (Auboyer 2002). Over the centuries the custom died out in the south only to become prevalent in the north, particularly in the states of Rajasthan and Bengal. While comprehensive data are lacking across India and through the ages, the British East India Company recorded that the total figure of known occurrences for the period 1813 - 1828 was 8,135; another source gives the number of 7,941 from 1815 - 1828, an average of 618 documented incidents per year. However, these numbers are likely to grossly underestimate the real number of satis as in 1823,575 women performed sati in the state of Bengal alone (Hardgrave 1998).

Historically, the practice of sati was to be found among many castes and at every social level, chosen by or for both uneducated and the higher caste ranking women of the times. The common deciding factor was often ownership of wealth or property, since all possessions of the widow devolved to the husband's family upon her death. In a country that shunned widows, sati was considered the highest expression of wifely devotion to a dead husband (Allen \&Dwivedi 1998, Moore 2004). Because its proponents lauded it as the required conduct of righteous women, it was not considered to be suicide, orelse otherwise it would have been banned or discouraged by the Hindu scripture. Sati also carried romantic associations. Stein (1978) states "The widow on her way to the pyre was the object (for once) of all public attention...Endowed with the gift of prophecy and the power to cure and bless, she was immolated amid great fanfare, with great veneration". Only if she was virtuous and pious would she be worthy of being sacrificed; consequently being burned or being seen as a failed wife were often her only choices (Stein 1978). Indeed, the very reference to the widow from the point at which she decided to become a "Sati" (Chaste One) removed any further personal reference to her as an individual and elevated her to a remote and untouchable context. It is little wonder that women growing up in a culture in which they were so little valued as individuals considered it the only way for a good wife to behave. The alternative, anyway, was not appealing. After the death of a husband a Hindi widow was expected to livethe life of an aesthetic, renouncing all social activities, shaving her head, eating only boiled rice and sleeping on thin coarse matting (Moore 2004). To many, death may have been preferable, especially for those who were still girls themselves when their husband's died. 
Contemporary studies on widowhood have challenged many traditional challenges ( SATI, PROPERTY INHERITANCE, TORTURE FROM IN-LAWS LEADING TO DEPRESSION , TRAUMA \& OTHER HEALTH HAZARDS ). Moreover, THE CHANGING LIVES OF OLDER PEOPLE have thrown light on new theoretical frameworks about how people perceive WIDOWHOOD. Over last few years there has been decibel noise for women's rights specially on WOMEN ATTROCITIES focusing on WIDOWHOOD problems. Though the widows has been considered as a separate class, but now-a-days this gap is reducing due to the changed perception of the people, because of modern education, rapid modernization and globalization. Over the past two to three decades the Government, Citizens, Voluntary organizations,NGOs have become conscious about gender discrimination in general, and discrimination against Widows in specific. It basically leads to affirmative actions like welfare measures, empowerment effort and limitation of the research to understand the problem of women and widows, in particular. This has been a multidisciplinary as well as an interdisciplinary effort to understand the impact of the problems of widowhood being impinged in our religious texts . Moreover, this would infact help for furthering the research in analyzing the various causes related to widowhood and for finding a remedial approach.

Basicallyin ancient India, women occupied a very important position, in fact a superior position to, men. It is a culture whose only words for strength and power are feminine -"Shakti" means "power" and "strength." All male power comes from the feminine. Literary evidence suggests that kings and towns were destroyed because a single woman was wronged by the state. For example, Valmiki's Ramayana teaches us that Ravana and his entire clan was wiped out because he abducted Sita. Veda Vyasa'sMahabharatha teaches us that all the Kauravas were killed because they humiliated Draupadi in public. ElangoAdigal'sSillapathigaram teaches us Madurai, the capital of the Pandyas was burnt because PandyanNedunchezhiyan mistakenly killed her husband on theft charges.

In Vedic times women and men were equal as far as education and religion was concerned. Women participated in the public sacrifices alongside men. One text mentions a female rishi Visvara. Some Vedic hymns, are attributed to women such as Apala, the daughter of Atri, Ghosa, the daughter of Kaksivant or Indrani, the wife of Indra. Apparently in early Vedic times women also received the sacred thread and could study the Vedas. The Haritasmrti mentions a class of women called brahmavadinis who remained unmarried and spent their lives in study and ritual. Panini's distinction between arcarya (a lady teacher) and acaryani (a teacher's wife), and upadhyaya (a woman preceptor) and upadhyayani( a preceptor's wife) indicates that women at that time could not only be students but also teachers of sacred lore. He mentions the names of several noteworthy women scholars of the past such as Kathi, Kalapi, and Bahvici. The Upanishads refer to several women philosophers, who disputed with their male colleagues such as Vacaknavi, who challenged Yajnavalkya. The Rig Veda also refers to women engaged in warfare. One queen Bispala is mentioned, and even as late a witness as Megasthenes (fifth century B.C. E.) mentions heavily armed women guards protecting Chandragupta's palace.

Louis Jaccoliot, the celebrated French author of the Bible in India: Hindoo Origin of Hebrew and Christian Revelation said: "India of the Vedas entertained a respect for women amounting to worship; a fact which we seem little to suspect in Europe when we accuse the extreme East of having denied the dignity of woman, and of having only made her an instrument of pleasure and of passive obedience." He also said: "What! here is a civilization, which you cannot deny to be older than your own, which places the woman on a level with the man and gives her an equal place in the family and in society."

\section{THE STATUS OF WOMEN AS DEPICTED BY MANU IN THE MANUSMRITI}

The Manusmriti also known as ManavDharamShastra, is the earliest metrical work on Brahminical Dharma in Hinduism. According to Hindu mythology, the Manusmriti is the word of Brahma, and it is classified as the most authoritative statement on Dharma.The scripture consists of 2690 verses, divided into 12 chapters. It is presumed that the actual human author of this compilation used the eponym 'Manu', which has led the text to be associated by Hindus with the first human being and the first king in the Indian tradition.

Although no details of this eponymous author's life are known, it is likely that he belonged to a conservative Brahman class somewhere in Northern India. Hindu apologists consider the Manusmriti as the divine code of conduct and, accordingly, the status of women as depicted in the text has been interpreted as Hindu divine law. While defending Manusmriti as divine code of conduct for all including women, apologists often quote the verse: "yatrnaryastopojyantay, ramantaytatrdevta[3/56](where women are provided place of honor, gods are pleased and reside there in that household), but they deliberately forget all those verses that are full of prejudice, hatred and discrimination against women. 


\section{PORTRAYAL OF WOMEN IN THE HINDU EPICS}

The ancient Hindu-Indian society in respect to women is seen from two different perspectives. One is by Brahmins/Upper-caste originating from Indian antiquity, secondly by Dalits/liberalists. During the Vedic period, roughly 1500 to 600 B.C, Manusmriti also known as Manu Dharma Shastra, the ancient Hindu Code of conduct for domestic, social and religious life was written in Sanskrit by the Manu. Even today thisManusmriti is quoted both by liberal and conservative groups. Liberal groups opposing current use of the practices of this ancient Indian code is seen as a culture that dominates women and denies the, freedom and empowerment. Conservatives, on the other hand, consider modern culture to be evil to India and desire the return of the Manusmriti. The conservative group has many political wings such as BharatiyaJanata Party (BJP) and Shiva Sena who ruled India from 1999 to 2004.

The pro Manusmriti people, including some Indian feminists, argue that women are treated well and respected by Manu. They ask the modern feminists to take examples from Manusmriti.But Indian Liberal feminists and Dalits view the Manusmriti as anti-women and anti-Dalit text, where women and Dalits are degraded. Ambedkar in his article "The Rise and Fall of Hindu Women" argues that Hindu religion through its religious texts, such as the Manusmriti always degraded women.

SitaAgarwal's analysis of the degradation of women in the Vedic period, argues that the continuation of the Vedic religions which collectively referred to as Brahminism is the reason for degradation of women. Ruth Manorama, a Dalit Christian feminist scholar and social activist from Tamil Nadu, traces the roots of the degradation ofDalits and Dalit women to the Manusmriti According to Manu, women are not allowed to do any work independently either inside the house or outside the house. In the childhood she has to be under the control of her father and brothers and after marriage she is under the control of her husband. SurendraJondhale observes that the ancient Hindu text Chaturvanya treated women as Dalit. Undeniably, in the ancient Hindu religious texts, the "entire Dalit society including men and women did not have equal economic rights. Lower caste women are doubly discriminated: caste and gender. Manu considered women as slaves." SurendraJondhale has the same criticism of Manusmriti for making the women and Dalits inferior to other people; thus the "[p]sychological, social and cultural proscriptions unleashed by Manu restricted her autonomy." This lower status of women continued even in the 1000 years of the Muslim rulers and through the Medieval India.

The laws of Manu still are practiced at present time. As Sonia Mahey observes, “[t]he horrendous Laws in the Manusmriti were incorporated into Hinduism because they were favourable only to the Upper castes which form the majority of India. Even today, in modern times, we see the severe oppression and exploitation of Dalit women." Certainly, the Indian social order has been built upon the pillars of the Manusmriti says KumudPawde. Since the Code of Manu (Manusmriti) intermingles with the Indian culture and Hindu religion, itvery

hard to remove those anti- Dalits and anti-women texts in Manusmriti; people consider it as sacred. Therefore, SitaAgarwal suggests; "Since such passages cannot be deleted in modern times, nor can the Vedas be modified, it hence follows that all Indian feminists must fight against any and all forms of Vedic religion. Unless they do so, Indian women shall forever remain enslaved to Vedic tyranny."

Unlike Abrahamic religions (Judaism, Christianity and Islam) or even like Buddhism, there are supreme goddesses in Hindusm. Shakti (a female goddess) is considered the mother of all gods, a creator and destroyer. Shakti means power. She is powerful goddess. In the Hindu tradition there are three supreme gods: Brahma, the lord of creator, Vishnu, the lord of protector, and Shiva, the lord of destroyer. These three supreme god's consorts, namely, Saraswati (wife of Brahma), Lakshmi (wife of Vishnu) and Parvati (wife of Shiva) are also considered as goddesses and patrons. Saraswati is the patron of knowledge, Lakshmi is the patron of wealth and Parvati is the patron of power. Even now there are numerous Temples dedicated to this goddess. Apart from these three big female deities the other important deities are: Kali and Durga are considered as both creative and destructive power of time.

However, Hindu religion through its mythology and epics continues to keep the women at the low level. In the Hindu-Indian mythology five women are portrayed and showed as role model for other women. They are Sita, Savitri, Draupadi, Ahalya and Arundhati. Sita is the obedient wife of the Ramayana epic's god, Rama. Her obedience is shown also to her brother-in-law. In the case of failure of this obedience, she will face problems and hardships. The epic tells that Sita disobeyed her brother-in-law and, consequently, was abducted by the evil person Ravana. The lesson from this epic is that wife should obey if not she will suffer. Another story of suffering and obedient wife is contained in the Mahabaratha epic. This second "model" woman is Savitri. She is a queen chooses a blind the one who is going to die soon, as a marriage partner. She is given as model as the one who suffered and scarified her life for the sake of her husband. Savitri is shown as an ideal wife. Dr. R. Dhanjal observes that for the low and degradation position of women is due to 
the ongoing cultural and religious mind set up imposed on Indian women. Dhanjal says; "All men want their wives to be like Sita - long suffering and obedient. The lot of most Indian women today is similar to that of Savitri and

Sita,

but

with

slight difference." Dhanjal further says; "Modern-day Indian women put up with indignity and degradation from sheer economic necessity, being not trained for any profession. Taught from childhood that a husband's word is law, most find it easier to suffer rather, than leave the security of the home to look for a job to support themselves and their children. That is one reason for the low divorce rate in India."

The third role model for women is Draupadi. Her story comes in the epic of Mahabaratha. Draupadi is the wife for five princes. Although she was married to only one prince later she was asked to be the wife for her four brother-in-laws. She kept silent and obeyed her husbands even in the extreme situation when she was gambled away by one of her five husbands. In the gamble her husbands were defeated and they were sent to exile for 13 years. Even in these critical and painful situations she kept quiet, obeyed and accompanied her husbands wherever they went. Never raised her voice against her husbands behavior. Ahalya an epic woman narrated in the Ramayana is the fourth one. Ahalya is the wife of Gautama a Hindu rishi (hermit). She was seduced by god Indra and had sexual relationship with god Indra when she was unconscious. Due to her infidelity she was cursed by her husband to become stone. Ahalya's life is shown as an example to Indian women that if any wives are seduced by other men will be punished by their husbands even if it happens without the consent of the women. Even though the wives are not responsible for the seduction they have to undergo punishment. The fifth woman is Arundhati the wife of Vashishta a sage. Her story is narrated in many Hindu epics. She is shown as model for her chastity.

The Hindu-Indian tradition again and again imprints in the hearts and minds of the women that women should obey to her husband undergo suffering and should be chaste. If they violate this tradition they will face the same problems as the Hindu epic women faced. Margaret R. Higonnet observes it was the duty of the women to prove that they are chaste. She says; "As traditional narrative model, these legends (Ahalya and Sita) propose purification for the violated woman through symbolic death (transformation into a stone, passage through fire), to resolve the crisis of rape or attempted rape." KailashVijayavargiya, a BJP political party minister in Madhya Pradesh,quoting Ramayana, Vijayavargiya said just like Sita was abducted by Ravana, a woman will be punished if she crosses her limits,"commented following the gang rape and murder of 23 years old girl in New Delhi. In the same context, Mohan Bhagwat the RSS (a Hindu fundamentalism part) leader, commented that "A husband and wife are involved in a contract under which the husband has said that you should take care of my house and I will take care of all your needs. I will keep you safe. So the husband follows the contract terms.

the time, the wife follows the contract, the husband stays with her, if the wife violates the contract, he can disown her." Commending the Bhagwat statement, Brinda Karat, CPI (M) communist political party leader, said the Hindu fundamentalist groups want to create a new Indian constitution based on $\quad$ Manushriti.

Some modern Indian feminists, however, re-interpret those epic model women in the eyes of modernliberal feminism. Sunita Thakur tries to re-envigorate people's memory and honoring of those disobedient characters from those five role model Hindu epic women. Thakur says Sita when she was to prove her chastity by her husband, refused, instead returned to her mother house. In the same way, Draupadi when she was gambled away by her five husbands, refused to obey but demanded war for justice.

Famous Women within Hinduism

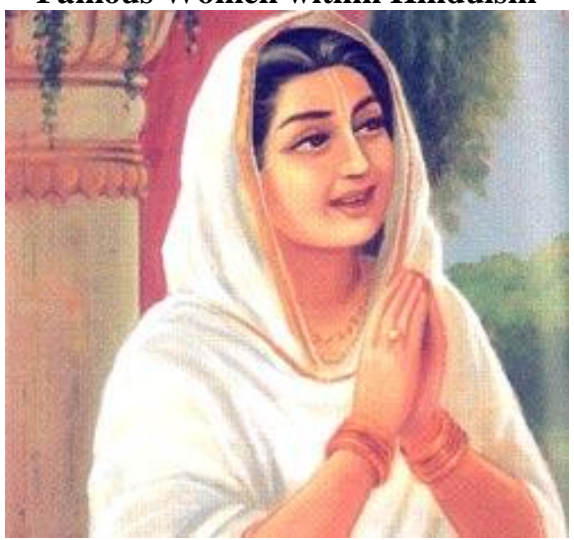


Queen Kunti, heroine of the Mahabharata, is famous for her heartfelt prayers to Lord Krishna. She wears the white saree of a widow.

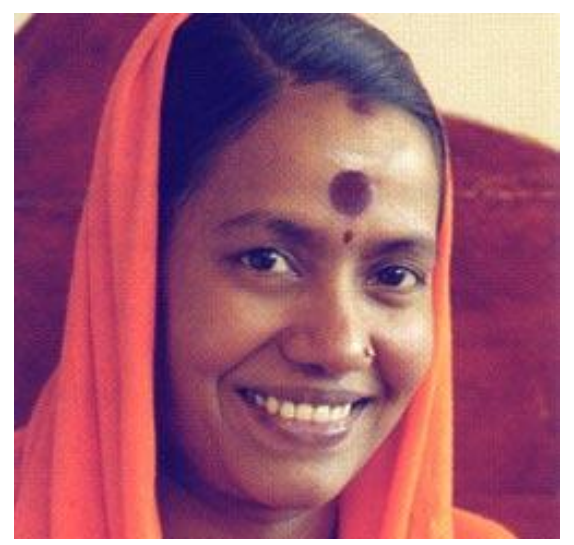

Today, Hindu women are prominent in all walks of life. Worldwide popularity has favoured a number of female gurus, such as Mother Meera, "Nirmila Devi, and Amritanandamayi Devi. Indira Betti is particularly well-known in Britain. Mother Gayathri, a popular guru in Britain, is shown here.

Hindu scripture, particularly of the earlier period, places great value on contributions of women. The muchreported abuses of women in India demonstrate a falling away from traditional practice. Many famous women serve as lasting role models, though with the influence of feminism such values are less popular with the younger generation or need reinterpretation to suit the current social context.

Such famous figures are extremely diverse and include deities (such as Sita and Parvati), historical or mythological figures (such as Draupadi from the Mahabharata), political activists (for example, the Queen of Jhansi), and saints and spiritual leaders (e.g. Mirabai and Anandamayi). A more complete list is given below.

- Sita - The wife of Lord Rama, considered part of the Godhead. For many Hindus, Sita is the ideal example of womanhood and a dutiful wife.

- Kunti - The mother of the five Pandava princes. Her devotion to Lord Krishna never faltered even in great adversity. She is one of the "five virtuous women." The others are Draupadi (see below), Mandodari (the wife of Ravana), Ahalya (wife of the sage Gautama), and Tara (the wife of Vali, the mDraupadi - The wife of all five Pandavas. She was insulted in the royal court and, as a result, millions of warriors perished on the plains of Kurukshetra. A chaste yet powerfully assertive woman, she displayed both fiery anger and remarkable compassion.

- Damayanti - Wife of Nala.Together they demonstrated unflinching devotion to each other.

- Savitri - By her selfless devotion she saved her husband from the court of Yama, the Lord of Death.

- Andal (725-755) - The only woman amongst the South Indian Alvars (poet mystics). Andal was so overwhelmed with love for Vishnu that she refused to marry anyone else. According to tradition she merged into the deity of Vishnu after being formally married to him.

- AkkaMahadevi (12th century) - A medieval women saint with an unusually modern outlook. She was devoted to Lord Shiva. The Lingayats venerate her as a symbol of the equality of women and as an early exponent of women's emancipation.

- Mirabai (1547-1614) - Great saint, born in a royal family and famous for her songs and her devotion to Lord Krishna, whom she considered her eternal husband.

- The Queen of Jhansi (1835-1858) - Famous for fearlessly fighting against the British.

- Kasturaba Gandhi (1869-1944) - Wife of Gandhi; still greatly honoured as a devoted wife by the Hindu community.

- Helena Blavatski (1831-1875) - One of the early foreigners (from Russia) to take up Hiduism, she cofounded the Theosophical Society in 1875 along with Annie Bessant(1847-1933), an English woman and prolific writer, who became the society's president in 1907.

- Anandamayi (1896-1982) - A well-known female yogi from Bengal with a large following and many centres throughout India. She is credited with many miracles.

\section{Sita}

The daughter of King Janaka. She is the heroine of the Ramayana. As Rama's only wife, she resolved to undergo the hardships of forest life rather than leave her husband. Out of infatuation for her, the tyrant Ravana met his ignoble end. After he kidnapped her, she refused to submit to his adulterous advances. Sita is 
considered to embody all the virtues of a traditional Hindu woman and has been held up as a role model for Hindu girls to follow. Some modern feminists have objected to this notion as being sexist.

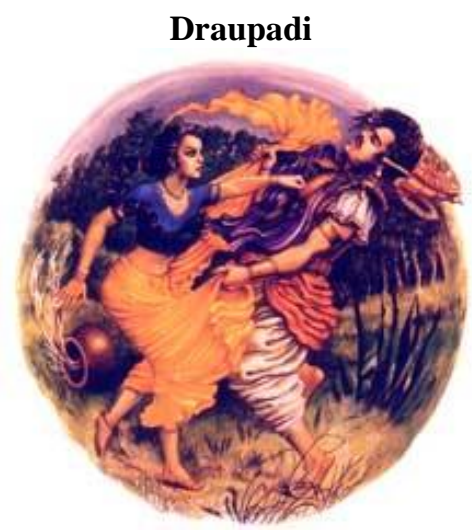

A central figure in the Mahabharata. Born of the sacrificial fire in King Drupada's court, she became the common wife of all five Pandava brothers. King Jayadratha tried to kidnap her, and she fought like a true warrior queen. She demonstrated how a traditionally devoted wife can also be powerfully assertive.

Once, Yudhisthira lost her in a rigged gambling match and the Kauravas tried to disrobe her before the entire royal assembly. In the attempt to strip her, the kings present failed to intervene, and thus sowed the seeds of their destruction on the plains of Kurukshetra. The Mahabharata thus illustrates the ancient ideal of valuing and protecting women, and the terrible consequence of neglecting or exploiting them.

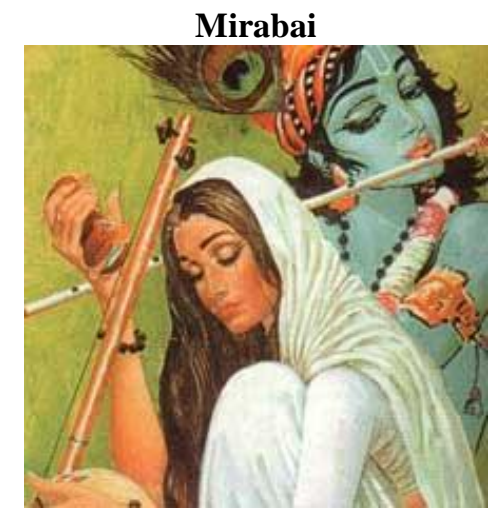

Although many Hindu heroines exemplify the traditional role of women, others have opposed or transcended tradition when it declined into abuse. Mira was one such example. Born in 1547 in a Rajput (warrior) family in Rajastan, she became an ardent devotee of Krishna. At a young age, she resolved that only he could be her future bridegroom. She was, however, duly married into a Shakti-worshipping household. She refused to abandon the worship of Krishna for the Goddess, and was victimised by her husband. She left for Vrindavana, but returned when her husband reformed. Upon his death, she refused to perform sati and was persecuted by her husband's family. The new king tried to kill her but by Krishna's grace she survived. She finally abandoned her husbans's palace to lead the life of a wandering saint. She sang and danced in public, unconcerned for social decorum and finally it is said that she mystically entered a murtiof Krisna. Her poems and songs express her intense feelings for Krishna and are still sung and recited by devotees today.

Versions of To construct a reliable chronology of Hinduism is challenging, for the following reasons:

- Hinduism claims no identifiable human founder, nor a specific origin in history.

- It is so old that its past recedes into pre-history. Furthermore, the tradition itself claims to be eternal.

- Hinduism is extremely diverse, and only recently conceived of as a single, distinct religion. Hindus did not feel compelled to unify their many traditions, or define the common ground that distinguished them from "other faiths" — not, at least, until these "others" threatened to impose their own doctrines.

- Hindu people were little concerned with recording "mere facts"; they were interested in the meaning behind events, not a resume of the past. First-hand records are therefore relatively rare. 
- Within the accounts that are available, there is no clear divide between history and myth; written narratives span many eras of time and planes of existence. They are not limited to descriptions or eulogies of a single country, race or religion.

Nonetheless, researchers have drawn up a timeline for Hinduism, as they do for other religions. Most textbooks identify the roots of Hinduism with the Aryan migration into India, around 1500 BCE, and the subsequent composition of the Rig Veda. European scholars proposed this theory in the late 19th century. It was controversial from the start and some academics, especially from India, now consider it an example of colonialmissionary interpretation - a predominant culture projecting it own ideas, values, and biases onto the politically depeEuropeans considered India backward, thinking that anything valuable found there must have been imported from the "civilised" West. Significantly, within ancient Indian texts there is no mention of any Aryan migration. The term Aryan (see glossary) was used, but not to refer to a specific race of people. As scholars continue to debate the theory, a new chronology is emerging, often reversing the paradigm by proposing India as the cradle of civilisation, and pushing dates further back. This is more consistent with Hindu versions of history, with their much earlier dates, and numerous textual references to Vedic societies migrating westward.

The table below, although not completely consistent with the tradition's view, is a commonly presented picture. It has been simplified to include only more relevant elements and modified to accommodate results of more recent research. Naturally, all dates are somewhat tentative. The seven periods shown below are discussed in the Europeans considered India backward, thinking that anything valuable found there must have been imported from the "civilised" West. Significantly, within ancient Indian texts there is no mention of any Aryan migration. The term Aryan (see glossary) was used, but not to refer to a specific race of people. As scholars continue to debate the theory, a new chronology is emerging, often reversing the paradigm by proposing India as the cradle of civilisation, and pushing dates further back. This is more consistent with Hindu versions of history, with their much earlier dates, and numerous textual references to Vedic societies migrating westward.

The table below, although not completely consistent with the tradition's view, is a commonly presented picture. It has been simplified to include only more relevant elements and modified to accommodate results of more recent research. Naturally, all dates are somewhat tentative. The seven periods shown below are discussed in the Ancient History, and Medieval and Modern History section

\section{A HINDU CHRONOLOGY}

3,000-1500 BCE: Indus Valley Civilisation (Old Chronology), or

6,000-1900 BCE: Indus-Sarasvati Civilisation (New Chronology)

1500-500 BCE: Vedic Period (some say, beginning with the Aryan migration)

500 BCE-500 CE: Epic, Puranic and Classical Ages

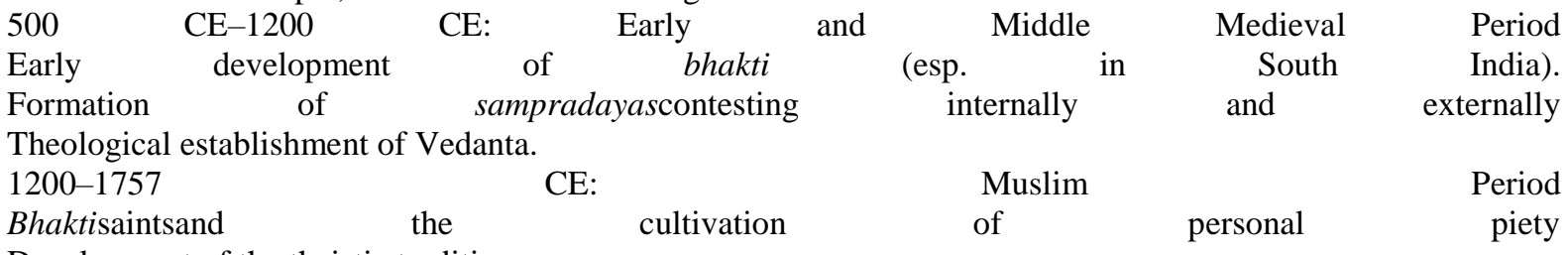

Development of the theistic traditions

1757-1947 CE: British Period .

The reform movements and birth of neo-Hinduism

1947 CE-present:

Migration

Independent

India

to

Britain

Hinduism established as a world religion.

\section{Quote}

"In Hinduism, the momentous event of a foundation at one point in time, the initial splash in the water, from which concentric circles expand to cover an ever-wider part of the total surface, is absent. The waves that carried Hinduism to a great many shores are not connected to a central historical fact or to a common historic movement."

\section{PERSONAL REFLECTION}

Contemporary discourse on widowhood in India tends to concentrate heavily on quantitative evaluation. Discussion of the narratives of the women is confined to more popular medium, and tends to focus on the need of the women to be empowered. By simply visiting ashrams in Vrindavan it becomes clear that the term "empowerment" is vastly up to interpretation. This study focuses on the models of empowerment applied by two different widow ashrams: Ma-dham and Chetan Bihar. Through obtaining narratives of the women's lives, I attempt to assess the success of the ashrams in "empowering" the widows, and question the necessity 
and implications of this empowerment. There seems to be no unified vision of what constitutes empowerment for any two women to the extent that while most dislike the state of widowhood, a significant and surprising number seem to prefer widowhood to marriage. In all, "empowerment of women", a phrase used by nearly every women's organization, is ambiguous and at times misused. In analyzing the situation of widows in Northern India, there emerges the need to distinguish between personal power and external empowerment by researchers in the field, as well as by the ashrams working to alleviate social injustice.

Within the normative structure of Brahmin gender roles is the assumption that the ban on remarriage of widows is reserved as a privilege for the higher castes . Less acceptable forms of marriage, derived from the eight forms listed in the Hindu shastras were ascribed to the lower castes, namely a system of remarriage known as pat which is prevalent among the agriculturalists. Because women in these societies are seen as producers - and reproducers of producers - their continued sexual activity after widowhood is viewed in parallel to the success of their economy.

For these reasons, a historical divide has been created between terms of widowhood for the higher and lower castes. While this ancient delineation of widowhood is still considered an idealized space for a widow to inhabit, the extent to which any given woman adheres to these structures today is largely dependent upon a variety of factors, including socio-economic status. 9 Because of these financial considerations, many widows from lower-income families are not able to remain in the house of their in-laws without working or, in some circumstances, getting remarried. Oftentimes, if these women cannot, or do not wish to, work or remarry, they will leave their family structure for a variety of reasons. Some of these include, but are not limited to, a desire to relieve the burden on their family, a lack of connection to their in-laws or children, or a wish for independence from a life of familial ties. Hindu widows commonly relocate to religious pilgrimage sites, including Vrindavan and Varanasi - the birthplaces of Lord Krishna and Lord Shiva, respectively.

Needless to say, lifestyles and identities adopted by widows are highly individualized, and essentially no two women's stories are exactly the same. Perhaps the most difficult factors to assess among these actions are those of personal choice and empowerment. If a widow leaves her house after her husband's death, rather than remain with either her children or her in-laws, is that a matter of choice? Is the widow who leaves her family more or less empowered than the woman who stays? How subjective is empowerment, and can we ever define it objectively? Can we, as researchers, ethically define empowerment for another group of people, or is there an aspect of condescension in doing so?

\section{REFERENCES}

[1] Brick, David (April-June 2010). "The Dharmasastric Debate On Widow Burning".Journal Of The American Oriental Society. 130 (2): 206-211.

[2] Sharma, Arvind (1988). Sati: Historical And Phenomenological Essays. Delhi: Motilalbanarsidass Publ. P. 102, Footnote 206. Isbn 9788120804647.

[3] Brick, David (April-June 2010). "The Dharmasastric Debate On Widow Burning".Journal Of The American Oriental Society. 130 (2): 212-213.

[4] Arvind Sharma (1988), Sati: Historical And Phenomenological Essays, Motilalbanarsidasspubl, Isbn 9788120804647, Page Xi, 86 